\title{
A Survey on Ethnomedicinal Plants of Pechipparai Hills, Southern Western Ghats of Tamilnadu, Kanyakumari District
}

\author{
Article by J.Carolin Joe Rosario \\ Department of Botany, Nirmala College for Women, Coimbatore \\ Email:- cjoerosa@gmail.com
}

\begin{abstract}
The present ethno-medicinal study was carried out at 3 localities of Pechipparai hills of Southern Western Ghats of Tamilnadu, Kanyakumari district. Frequent field visits were made throughout the study period from 2012-2013. Data presented here are based on personal observations and interviews with informants like medicine men and village head men. In this context the Kani people has rich and abundant terminology. It is common that most of the medicinal plants have their own secret, for many safeguard their specialized knowledge. During the present course of investigation, a total 50 medicinal plant species were distributed across eighteen families and fifty genera. The result of the present study provide evidence that medicinal plants continue to play an important role in the health care system used by tribal community. Documentation of this knowledge is valuable for the communities and their future generations.
\end{abstract}

Keywords: Medicinal plant, ethno-medicine, Kani people, Western Ghats.

\section{Introduction}

Plant products are used as the main source of medicine throughout the world for treating various diseases. About $50 \%$ of the present day medicine in the United Nations of America are derived from natural sources especially from various plants. The uses of traditional medicine in both developing and developed countries is significantly increasing in recent time. There is growing demand for the types of medicines like Ayurveda, Siddha, Unani and Homeopathy. During the last two decades scientists all over the world are playing much more attention to the study of an ever branch of science Ethno-biology especially to tribal or ethno-medicine. Ethnomedical practices are preferred largely because medicinal plants are less expensive, readily available and reliable, and they are considered to have fewer side effects than modern medicines.

The World Health Organization (WHO) estimates that over 80 percent of people in developing countries depend upon traditional medicine for treatment of disease and other maladies in their primary health care. India is one of the leading countries in Asia in terms of the wealth of traditional knowledge systems related to the use of plant species and also known to harbor a rich diversity of higher plant species of which 7500 are known as medicinal plants (Kala, 2005). These tribal communities draw their sustenance largely from forests for food medicinal and other requirements. (Janaki Ammal, E.K et al., 1984) .

Our country has one of the largest concentrations of the tribal communities in the world. About 68 million tribe people belonging to 573 tribal communities living in different geographic location in our country. Plants play a vital role for the existence of life on the earth and the uses of plant source of medicine is as old as humanity. Since most of this ethnic community do not have their over scripts and written language, the information about prescriptions, pharmacology, attitude towards diseases of the old age etc (Schultes, R.E, 1962)., The people belonging to modern societies are not aware of this rich knowledge system. Inspite of the fact the studies in tribal medicine have enabled to identify 1600 new drug yielding plants. (Ayyanar.M et al., 2005). Thus it has become imperative to collect information and document the same and study them scientifically. 
Tribal are in general the followers. It leads to the belief that diseases and death are caused by certain spirits super natural power. These belief have a great influence on their attitude and Psychology about the ailments. In general the tribal people give name to the plants with known good or bad properties. Thus more than one local name have been attributed to a plant which generally creates confusion to ascertain the actual plant species. (Ngari E.W, et al., 2010)

There are wide range of animistic conceptions associated with vegetation groves and forest worships. The tribals are in belief of supernatural power and have doctrine that the landmark things like big trees and unique vegetation of medicinal plants. (Usha.M, 2012) Useful plants near or inside the tribal villages are protected for respective utility. (Ignacimuthu et al., 1998) In many cases they never take whole plants or all fruit for the use but they leave some reproductive parts for next generation. They avoid harvesting medicinal plants in the evening. Some vegetables are not consumed at the ripening stage of the fruit.

The main objective of the ethno-botany is not only to trap the old traditional folk knowledge but also to testify the knowledge and to find out the new resources of various utilization. The present study is focused on the survey of ethno-medicinal plants in Pechipparai hills, Southern Western Ghats of Tamilnadu.

\section{Materials and methods study area}

The present study was carried at 3 localities (Valayamthuki, Alamparai, Andipothai) in Pechipparai hills of Southern Western Ghats of Tamilnadu, Kanyakumari district. $\left(8^{\circ} 03^{\prime}-8^{\circ} 35^{\prime}\right.$ $\mathrm{N}$ and $77^{\circ} 05^{\prime}-77^{\circ} 36^{\prime} \mathrm{E}$ ), which is located in the lap of western Ghats. This district covers an area of about $1684 \mathrm{sq} \mathrm{km}$, surrounded by three seas (Gulf of Mannar, Indian Ocean and Arabian Sea), Southern Western Ghats and plains of Kerala. The annual rainfall varies from $89-254 \mathrm{~cm}$, and maximum and minimum temperature were $24^{\circ} \mathrm{C}-28^{\circ} \mathrm{C}$ in winter and $28^{\circ} \mathrm{C}-32^{\circ} \mathrm{C}$ in summer respectively.

The present study of ethno-medicinal plants was carried out at 3 localities of Pechipparai hills of Southern Western Ghats of Tamilnadu, Kanyakumari district. Frequent field visits were made throughout the study period from 2012 -2013. Data presented here are based on personal observations and interviews with informants like medicine men and village head men. Plants were identified botanically using the Flora of Presidency of Madras (Gamble, 1915) and the Flora of Tamilnadu Carnatic (Mathew, 1983).

\section{Results and discussion}

Habit wise analysis of these medicinal plants indicates that majority of the plants belongs to shrub category. The highest proportion of Shrubs $(62 \%)$ is followed by herbs $(14 \%)$, climber $(14 \%)$ and trees $(10 \%)$. It was interesting to note that 50 plants are distributed among 28 families of these 47 plants belongs to dicots and remaining 3 plants constitutes the monocots (Table 1).

Table 1: Habit wise representation of medicinal plants

\begin{tabular}{|c|c|c|}
\hline Habit & No of Plants & Percentage \\
\hline Shrubs & 31 & 62 \\
\hline Herbs & 7 & 14 \\
\hline Climbers & 7 & 14 \\
\hline Trees & 5 & 10 \\
\hline
\end{tabular}

Based on the present study, it has been found that the tribal community of Pechipparai hill is rich in ethno-biological knowledge and this knowledge is being transmitted from one generation to another in the verbal form. Traditional medicines are the primary health care resources for the tribes to protect their health. 
During the present course of investigation, a total 50 medicinal plant species were distributed across eighteen families and fifty genera. The plants are arranged alphabetically with binomial name followed by habit, family, parts used and its uses were documented.

The dominant families with more number of medicinal plants in the present study are Euphorbiaceae (6 species) followed by Fabaceae, Verbenaceae and Lamiaceae (4 species each), Malvaceae, Oxalidaceae, Rutaceae, Asclepiadaceae, Solanaceae, Acanthaceae, Amaranthaceae and Liliaceae ( 3 species each), Tiliaceae and Vitaceae ( 2 species each). Four families were represented with only one species.

Table2: Plant part wise representation of ethnomedicinal plan

\begin{tabular}{|l|c|}
\hline \multicolumn{1}{|c|}{ Plants Used } & No of Plants \\
\hline Leaves & 22 \\
\hline Whole Plant & 11 \\
\hline Roots & 6 \\
\hline Seeds & 4 \\
\hline Bark & 2 \\
\hline Flowers & 1 \\
\hline Fruit & 1 \\
\hline Latex & 1 \\
\hline Stem & 1 \\
\hline Flowers & 1 \\
\hline
\end{tabular}

Most of the plants listed above are used in external application and some plants are used internally. A few plants are used in both ways. External applications is either in the form of poultice, oil paste or extract. For this preparation although root tuber, bark, stem, leaves and whole plants are used. The plants are used to make different preparations like Suranam, Kashayam, Thailam, Kulisai, Powder form etc. All these plants are available in tribal community and are used by the local people as home remedies. They have acquired this art from their ancestors. The plant part wise representation of the species indicates that highest part used is leaves followed by whole plant and other parts of the species (Table 2).

Our present study showed that the few ethno-medicinal plants belongs to the highest proportion of shrubs followed by herbs, climbers and trees. Though the plants are introduced from different parts of the hills, they influence the culture and the traditional system of the tribals. The local people utilize the medicinal plants for the treatment of several diseases.

\section{References}

[1]. Ayyanar M, Ignacimuthu S (2005). Traditional knowledge of Kanitribals in Kouthalai of Tirunelveli hills, Tamil Nadu, India. J.Ethanopharmacol.102:246-255.

[2]. Gamble J.S, (2008) (Rep.Ed) Flora of the Presidency of Madras 3 vols.

[3]. Gamble, J.S. (1996). The flora of the presidency of Madras (Adlard \& Son LTD, London vol. I - III.

[4]. Ignacimuthu, S, Sankarasivaraman. K Kesavan.L (1998). Medico Ethnobotanical survey among Kanikar Tribal of Mundanthurai sanctuary. Fitoterapia 69. 409-414.

[5]. Janaki Ammal E.K, Prasad P.N (1984) . Ethno botanical findings on Costus Speciosus among the Kanikkars of Tamilnadu. J.Econ.Taxon. Bot .5:129-133.

[6]. Kala C.P (2005). Current status of medicinal plants used by Traditional vaidayas in Uttaranchal state of India, Ethnobot . Res. Appl. 3: 267-278.

[7]. Matthew K.M (1983).The Flora of the Tamilnadu Carnatic. The Rapinat Herbarium, St.Joseph's college, Tiruchirapalli, India. vol: I - III. 
South American Journal of Medicine

Special Edition 2016

[8]. Ngari E.W, Chiuri L.W Kariuki S.T Huckett S (2010). Ethnomedicine of Nakuru - Kenya. Ethnobot. Res. Appl 8:135152 .

[9]. Prasad P.N. Jabadhas.A.W Janaki Ammal E.K (1987). Medicinal plant used by the Kanikkars of south India. J.Econ. Taxon. Bot. 11:149-155.

[10]. Schultes, R.E (1962). The role of ethnobotanist in search for new medicinal plants. Lloydia 25:257-266.

[11]. Usha, M.(2012).Ethnomedicines used by Kani tribals of Pechipparai hills, Southern Western Ghats of Tamilnadu, India, Plant Sciences Feed 2(1): 5-10 